\title{
椱合ファブリックの排水・補強両樴能を考虑した急勾配補強盛土の設計法式宋
}

\begin{tabular}{|c|c|c|c|}
\hline 棚憍由彦 & 長㟋大学工学部 & 和久田直学 & 大林組 (株) \\
\hline ○陶山健太 & 長㟋:大学大学院 & 安原一哉 & 茨城大学 「学部 \\
\hline 西村 淳 & 三非石化産資 (株) & 平井貴雄 & 三井石化産資 \\
\hline
\end{tabular}

概要

粘性土や建設副産物を盛土として用いたジオシンセティックス急勾配補強盛土が注目されている。 最近開発された複合ファブリックは、不織布と同様な排水機能を持ち、ジオグリッド以上の高剛性. 引張強度を有する。よって複合不織布を用いて火山灰質粘性土盛土の補強を行う場合、(1)排水材とし て使用して盛土の圧密促淮を図ることによる盛土本体の補強、(2)引張補強材として使用するこ上によ る盛土本体の補強の 2 つ補強効果を期待しているのが現状である。したがって、より経済的で合理

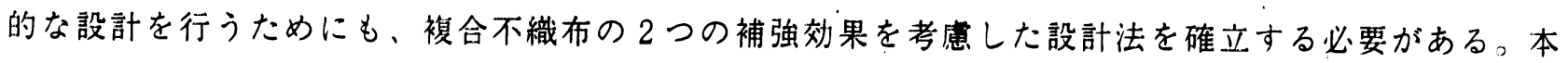
研究では、排水・補強両機能を同時に考慮した新しい設計法試案を提示する。

\section{New Design Method of Steep Earthfill Reinforced with Composite Fabrics Considering both Drainage and Reinforce Effects}

\author{
By \\ Yoshihiko TANABASHI, Naotaka WAKUDA \\ Kenta SUYAMA, Kazuya YASUHARA \\ Jun NISHIMURA, Tsutomu HIGASHI
}

\begin{abstract}
Recent development of new geosynthetics such as composite fabrics has been able to construct steep earthfill used high water content volcanic cohesive soils such as Kanto loam and /or even construction byproducts which have never been used as fill materials. Recent developed composite fabric has almost the same tensile strength of geogrid and of course drainage effect. However, current design method of the steep reinforce earthfill with nonwoven fabric has not considered its reinforced effect and strength increase of cohesive soil by consolidation. Therefore, this paper proposes a new design method of a steep reinforced earthfill taking strength increase of high water content volcanic cohesive soil by consolidation, A characteristics of soil-fabric interface and reinforced effect of composite fabric into account.
\end{abstract}




\section{椱合ファブリックの排水・補強両機能を考虎した急勾眍補強盛土の設計法武案}

$\begin{array}{cl}\text { 棚橋时彦 } & \text { 長崎大学工学部 } \\ \text { 和久明直孝 } & \text { 大林組 } \\ \text { ○陶山健太 } & \text { 長崎大学大学院 } \\ \text { 安原- -哉 } & \text { 茨城大学工学部 } \\ \text { 西村 淳 } & \text { 三井石化産資 } \\ \text { 平井員雄 } & \text { 三井石化産資 }\end{array}$

\section{1. 本研究の背貫}

近年、遊休地の減少や依然地価が高いこと、更には良質な土質材料の入手が困難な状況にあるこ とから、盛土材料に不向きな現場発生土の積極的再利用や、盛土を急勾配にする必要が生じてきた。 そのため、ジオシンセティックスを用いた補強土工法が積極的に採用されるようになってきた。従来 盛土材として用いられることのなかった関東ロームのような高含水比火山灰質粘性土でさえ、補強土 工法を採用することにより急勾配盛土の築造が可能になってきた。このような状況のもと、ジオシン セティックスにより粘性土高盛土を補強することが注目され、補強盛土の設計法に関する理論的研究 が活発になってきた。しかしながら、現行の設計法はいくつか不備な点があり、改善の余地が残され ている。

\section{2. 本研究の目的}

複合不織布は、不織布と同様な排水機能を持ち、 排水機能を持たないジオグリッドと同等の引張強度 を持つ特徴を有する。よって複合不織布を用いて火 山灰質粘性土盛土の補強を行う場合、(1)排水材とし て使用して盛土の圧密促進を図ることによる盛土本 体の補強 (図-1 (a))、(2)引張補強材として使用する ことによる盛土本体の補強(図-1(b))の 2 つの補強 効果が期待される。しかしながら、不織布は(1)の排 水材としての機能のみを期待し、設計を行っている のが現状である。したがって、より経済的で合理的 な設計を行うためにも、複合不織布の 2 つの補強効 果を考慮した設計法を確立する必要がある。本研究 の目的は、2つの補強効果を同時に考慮した新しい 設計法を提示することにある。

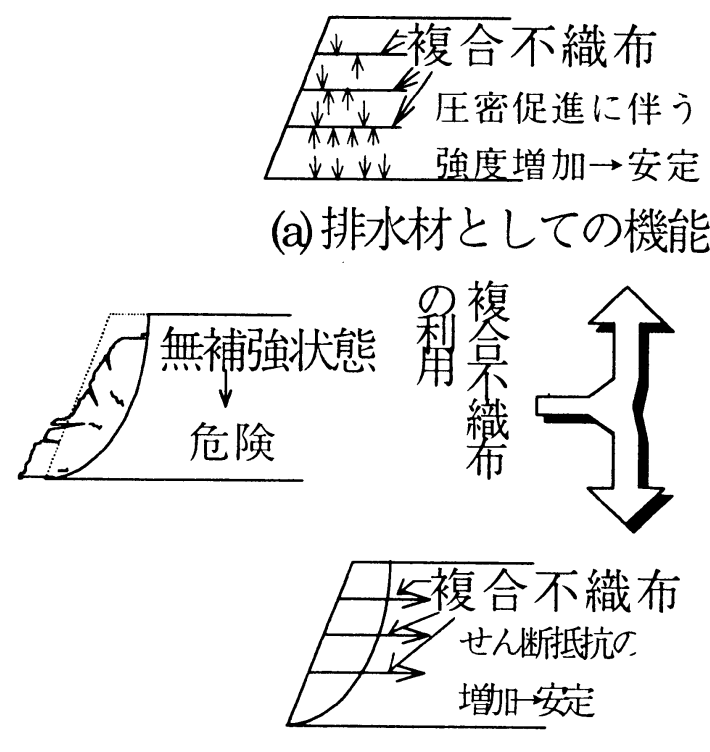

(b)引張補強材としての機能

図-1 複合不織布の補强効果 


\section{3. 既往設計法}

ジオシンセティックスを引張補強材とし て用いる時の次定解析法は、ジオシンセテ イックスに働！引張力がせん断強度の增加 に寄与してい々上考え、この時の安全蜜は 次式で与えられる。1

$$
F_{s}=\left(M_{R}+\sum R T_{i}\right) / M_{D}
$$

ここに $M_{k}, M_{p}$ : 抵抗および起動モーメン ト, $R$ : すべり円の半径, $T_{i}$ : 各層のジオ シンセティックスの引張力

本研究では、複合不織布が引抜けて破壊 するモードを䒓えているので、式（1）中の $T$, の值は引抜き抵抗力を採用する。ジオシ ンセティックスの引抜き抵抗力 $T_{i}$ は次式 で与えられている。

$$
T_{i}=L_{e} \cdot 2\left(c^{*}+\sigma_{v} \cdot \tan \phi^{*}\right) / F_{S m}
$$

ここに、 $T$ ： 引抜き抵抗力， $F_{s w}$ : 引抜 き安全率， $\sigma_{1}$ : ジオシンセティックス敷

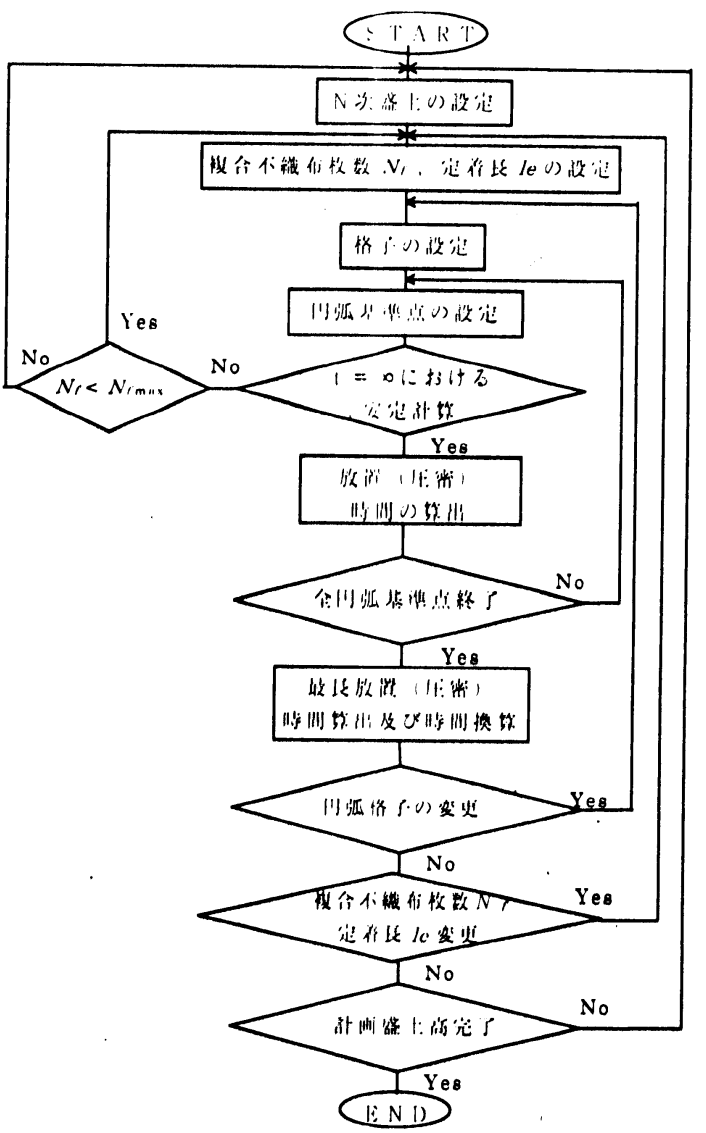

図-2 提案設計法のフロー 設位置での鉛直荷重， $L_{c} ：$ すべり面より奥 のジオシンセティックス定着長， $c^{*} ， \phi^{*}$ : 土とジオシンセティックスの間の粘着力, 世ん断抵抗角

式(2)中の $\dot{c}, \phi \phi^{*}$ は、土と補強材の摩擦特性を表す指標である。つまり、この引抜き抵抗力は土と 補強材間の摩擦特性と密接な関係がある。そのため、その摩擦特性を正確に把握しておくことが非常 に重要である。現行の安定解析法においては、盛土本体の圧密に伴う土と補強材との摩擦特性の変化 を考慮せず、摩擦特性は圧密の進行の程度に拘らず一様として計算している。すなわち、式(2)の $\dot{c}$, ф゙は圧密に伴って変化しないとしている。しかし、高含水比火山灰質粘性土の場合には压密に伴っ て、摩擦特性が变化する可能性が十分に考えられる。

\section{4. 提家設計法}

\section{1. 提实没䂥法の基本的流れ}

既往の設計法では、完成形を想定するため、圧密による摩擦特性の変化を考虑できない。1)そこで、 本設計法は、盛土段階を追うことで、压密に伴う摩擦特性の変化と盛土材料の強度增を考虑しょうと するものである。提案設計法のフローを図-2に示す。本設計法では N 次盛土を想定し、N-1 次以下盛 土の圧密による強度增を期待し、N次盛土の施工が可能となる圧密時間を求める。まず、N次盛土の 盛土厚, 複合不織布の枚数 $N_{f}$, 定着長 $l$ を を設定する。本設計法においては、盛土斜面の安定解析に 


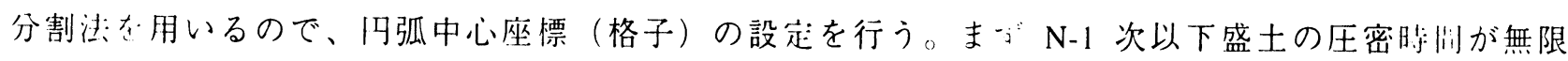
大として安定計算を行い、円弧中心崬標の一つでも安全率を満たさない点がある場合は、N潁土を

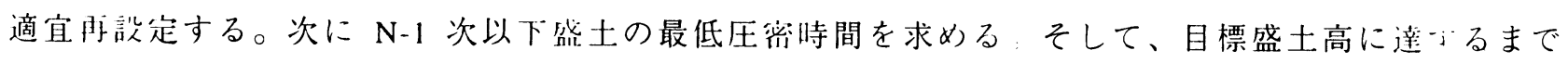
繰返し行う。なお、複合不織布の枚数, 定着長と最低圧密時閒の組合せは、盛土段階が進むにつれて 非常に多くなるので、適宜複合不織布の枚数, 定着長を変化させ計算を行う。

\section{2. 内的安定の計真法}

内的安定の計算法は、式(1)を基本式とする。本設計法の特徵は、圧密による土と複合不織布の摩 擦特性の変化を考慮することにある。压密の進行に伴って、土の強度は増加する。よって土○強度定 数の粘着力成分, 摩擦成分は圧密時間 $t_{c}$ の関数となる。また、複合不織布と土の摩擦特性も川密の進 行に伴い変化するものと考えられる。したがって、土の抵抗モーメント $M_{R}$ は次式で与えられる。

$M_{R}=R \cdot \sum\left(c_{c u}\left(t_{c}\right) \cdot l_{i}+W_{i} \cdot \cos \theta_{i} \cdot \tan \phi_{c u}\left(t_{c}\right)\right)$

ここに、 $c_{c u}\left(t_{c}\right), \phi_{c u}\left(t_{c}\right)$ : 圧密時間 $t_{c}$ における粘着力, 内部摩擦角, $l_{i}$ : 分割片で切られたすべり面の弧 長

次に引抜き抵抗モーメント $R T_{i}$ の $T_{i}$ は、複合不織布と土のせん断強度 $\tau_{f \mathrm{~s}}$ と定着長 $l_{\mathrm{e}}$ により次式で 与えられる。

$T_{i}=2 \tau_{f s}\left(t_{c}\right) \cdot l_{e} / F_{s m}$

$\tau_{f s}\left(t_{c}\right)=c_{c u s}\left(t_{c}\right)+\sigma_{i} \cdot \tan \phi_{c u s}\left(t_{c}\right)$

ここに、 $c_{c u s}\left(t_{c}\right), \phi_{c u s}\left(t_{c}\right)$ : 圧密時間 $t_{c}$ における土と複合不織布の摩擦特性, $\sigma_{i}$ : 複合不織布に作用する拘 束压

圧密による土と複合不織布の摩擦特性および土のせん断特性の変化は、定体積一面せん試験より求 まる。

\section{3. 压密時问の出出法及び换芷}

式(1)から、安全率に起動モーメントを乗じた值から未圧密層（N次盛土）の抵抗および引抜き抵 抗によるモーメントを引いた值が、圧密層に求められる必要モーメントとなる（式(1)の $M_{R}, T_{i} に は$ 未圧密層（ $\mathrm{N}$ 次盛土）分と圧密層（N-1 次以下盛土）分が含まれている)。压密層の抵抗及び引抜き 抵抗によるモーメントは圧密時間の関数であるから、圧密時間 $t_{c}$ を変化させ、必要最低圧密時間 $t_{c d}$ を求めることができる。変化させる $t_{c}$ は、実験値 $t^{\prime} に$ 変換させる必要があり、さらに層ごとに排水 距離が異なるので各々の変換が必要となる。盛土施工の実情と実験結果より、圧密時間の各々の換算 にはテルッァギの二乗則を用いることとする。求められた必要最低压密時間 $t_{c d}$ は、N-1 次盛土載荷 後の、 $\mathrm{N}$ 次盛土が施工可能となる圧密時間である。しかし、N-2 次以下盛土はそれ以前にも王密によ り強度增加している。したがって、ある時点の間隙比までの応力履歷は、それ以降の圧密沈下には影 響しないものと仮定し、以下にある層の換算圧密時間について述べる。沈下量 $S$ は平均圧密度Uの 近似式を用いると次のように表せる。2)

(I) 時間係数 $T_{V} \geqq 0.5$ の時 


$$
S=\frac{k \cdot H \cdot p \cdot\left\{1-8 \cdot{ }^{\left.\exp \left(-\pi^{2} c_{v} \cdot t / 4 H_{d}{ }^{2}\right) / \pi^{2}\right\}}\right.}{\gamma_{w} c_{v}}
$$

(II) 時間係数 $T_{V}<0.5$ の時

$$
S=\frac{4 k p \cdot \sqrt{c_{v} \cdot t / \pi}}{\gamma_{w} c_{v}}
$$

ここに、 $c_{v}$ : 圧密係数, $H_{d}$ : 排水距離, $\gamma_{w}$ : 水の単位体積重量, $k$ : 透水係数, $p$ : 圧密lE力力, $H$ : 層 厚

紙面の都合上、（II)を用いて説明する。図-3において線分 $\overline{\mathrm{OA}}$ は、次の盛土（ある層に対して $\mathrm{m}$ 層目）による自重圧密の 経路を示し( $\overline{\mathrm{AB}}, \overline{\mathrm{BC}}, \overline{\mathrm{CD}}$ は $\mathrm{m}+1 \sim \mathrm{m}+3$ 層目を盛る為に $\mathrm{m}+0$ $\sim \mathrm{m}+2$ 層の荷重と自重による圧密の経路)、 $t_{\mathrm{m}} \sim t_{\mathrm{m}+3}$ は圧密時 間， $t^{*}{ }_{\mathrm{m}+1} \sim t^{*}{ }_{\mathrm{m}+3}$ は換算圧密時間を表す。また、各々の傾きを $a_{m}$ 一 $a_{m+3}$ とする。ある層が、Bの沈下量を得るためには $\left(p_{1}, t_{m}\right)$ 加（ $\left(p_{2}, t_{m+1}\right)$ の応力経路を経る。もし、初めから $p_{2}$ の荷重 を受けていたならば、Bの沈下量を得るためには $\left(p_{2}, t_{m+1}+t^{*}{ }_{m+1}\right)$ という唯一の応力経路として表される。ある層に対して $\mathrm{n}$ 層目 を盛るためとし、実験值への変換（供試体の有効排水距離 $H_{d}{ }^{\prime}$ ) を含めた換算圧密時間 $t^{*}{ }_{n}$ を一般式として以下に示す。

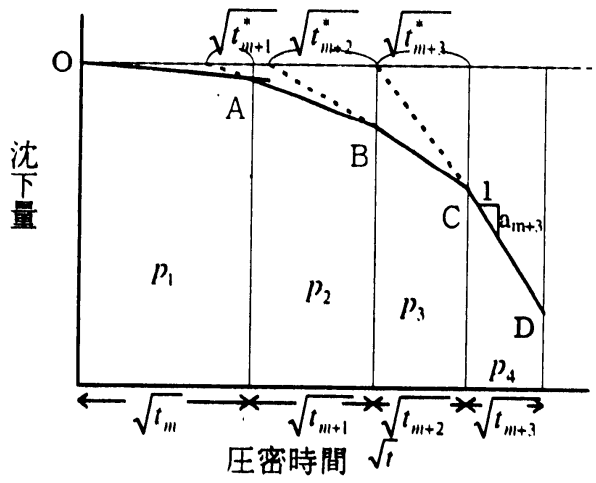

因-3 换算压密時问

$t_{n}^{* \prime}=\left(a_{n-1} / a_{n}\right)^{2} \cdot\left\{t_{n-1}^{* \prime}+t_{n-1} \cdot\left(H_{d}^{\prime} / H_{d}\right)\right\}^{2}$

$a_{n}=4 k p_{n} / \sqrt{c_{v(n-1)} \cdot \pi}$

ただし、 $a_{1}=0 \quad t_{1}=0 \quad t^{*}{ }_{1}, t^{*}{ }_{2}=0$ 。

同様にして求めた（I）の場合の一般式を示す。

$t_{n}^{* \cdot}=\left\{t_{n-1}^{* \cdot}+t_{n-1} \cdot\left(H_{d}^{\prime} / H_{d}\right)^{2}\right\}+\ln \left(a_{n-1} / a_{n}\right)$

$a_{n}=8 k H p_{n} \cdot \exp \left(-\pi^{2} c_{v(n-1)} / 4 H_{d}^{2}\right) / \gamma_{w} c_{v(n-1)} \pi$

\section{5. 提莱没計法の道用}

火山灰質粘性土のなかで代表的な関東ロームを飽和度規定で締め固め(施工含水比は自然含水比)、 補強材に複合不織布(TRF-31)を用いて築造される急勾配高盛土を想定する。

\section{1. 定体程一面せん断侙唤}

提案設計法に所要のパラメータ決定のために、関東ローム自身のせん断特性および関東ロームと複 
合不織布の糜擦特性を調べるための 2 種順の試験が必巍である。本研究では、これらの両試験を分体 積一面せん断試験で行った（三笠式改良型一面せん断闻験装置使用），

\section{（1）供試体初期条件}

関東ロームを $5 \mathrm{~mm}$ ふるいでふるい分けし、含水比訓整をしたもの芒用いた。関東ロームなどの火 山灰質粘性」: はその性質」、飽和度規定で締め固められる。飽和度規定では施工時の含水比や密度を 数值的に規足することはしていない。本仾究では、含水比と密度を設定した上で、供試体を作成する ため、これらの設定が必要となる。したがって、含水比 $w$ は自然含水比 $w_{n}=128 \%$ とし、湿潤密度 $\rho_{1}$

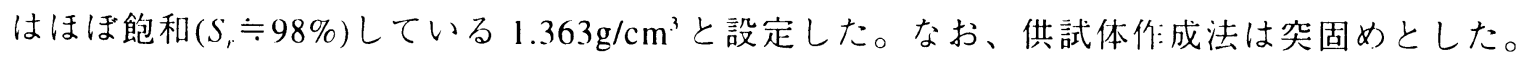

( 2 ) 試験条件:

関東ロームの標準圧密試験より、圧密降伏応力 $p_{y}$ は 1.5 $2.0 \mathrm{kgf} / \mathrm{cm}^{2}$ であった。また、一次圧密終了時間は 10２２分前後 である。これらより試験条件を定め、表-1に示す網掛け部分に ついて試験を行い、空白部は試験結果より内挿した。

\section{( 3 )試験結果}

関東ロームの粘着力および関東ロームと複合不織布の粘着力成 分は圧密時間によらずほほ一定であった。 $\tan \phi_{\mathrm{cu}(\mathrm{s})}$ と圧密時間 $t_{c}$ の関係を図-4に示す。関東ロームの $\tan \phi$ cu および関東ロームと 複合不織布の $\tan \phi_{\text {cus }}$ は压密時間と伴に増加し、一次圧密が充分 終了した後はほほ一定値になる傾向を示した。さらに、 $\tan \phi_{\text {cus }} / \tan$ $\phi_{\mathrm{cu}}$ が压密時間によらずほほ一定( $\left.\tan \phi_{\mathrm{cus}} / \tan \phi_{\mathrm{cu}}=1.1\right)$ であるという 注目に値する結果を得た。これは複合不織布の瀻維と関東ローム の土粒子との間に優れたか見合わせ効果が得られたものと考えら れ、用いた複合不織布は関東ロームに対して有意な摩擦抵抗を示

し、引張り補強材として有効に働くと判断できる。

\section{2. 安定解析}

(1) パラメータ

$$
c_{c u}\left(t_{c}\right)=0.322 \mathrm{kgf} / \mathrm{cm}^{2}, c_{c u s}\left(t_{c}\right)=0.196 \mathrm{kgf} / \mathrm{cm}^{2}, k=0.0042 \mathrm{~m} / \mathrm{min}_{\circ} \quad \phi_{c u}\left(t_{c}\right) お
$$
よ

び $\phi_{\text {cus }}\left(t_{c}\right)$ は、最も良い相関を示した次式で近似する(単位：度)。

$$
\phi_{c u}\left(t_{c}\right)=20.2-1 / \exp \left(-3.00+0.941 \sqrt{t_{c}}\right)
$$

$$
\phi_{\text {cus }}\left(t_{c}\right)=22.0-1 / \exp \left(-3.09+0.944 \sqrt{t_{c}}\right) \ldots
$$

$c_{v}=8.25 \times 10^{-6}+2.72 \times 10^{-6} \ln \sigma_{\mathrm{c}} \quad\left(\mathrm{m}^{2} / \mathrm{min}\right)$

ここに $\sigma_{\mathrm{c}}$ は压密圧力 $\left(\mathrm{tf} / \mathrm{m}^{2}\right)$
表-1 試験条件

\begin{tabular}{|c|c|c|c|c|c|}
\hline \multicolumn{2}{|c|}{} & \multicolumn{4}{|c|}{ 圧密压力 $\left(\mathrm{kg} / \mathrm{cm}^{2}\right)$} \\
\cline { 2 - 6 } \multicolumn{2}{c|}{} & 0.5 & 1.0 & 2.0 & 3.0 \\
\hline \multirow{2}{*}{ 密 } & 2 & $\bigcirc$ & $\bigcirc$ & $\bigcirc$ & $\bigcirc$ \\
\cline { 2 - 6 } 時 & 5 & & & & $\bigcirc$ \\
\cline { 2 - 6 } 間 & 10 & & & & $\bigcirc$ \\
\cline { 2 - 6 } (分) & 20 & $\bigcirc$ & $\bigcirc$ & $\bigcirc$ & $\bigcirc$ \\
\cline { 2 - 6 } & 30 & & & & $\bigcirc$ \\
\cline { 2 - 6 } & 60 & $\bigcirc$ & $\bigcirc$ & $\bigcirc$ & $\bigcirc$ \\
\hline
\end{tabular}

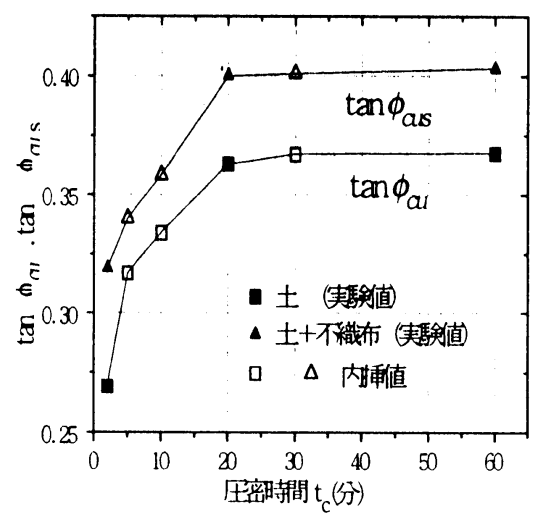

図 $-4 \tan \phi_{c u}, \tan \phi_{c u s}$ と 圧密時間 $t_{c}$ 閶俰 


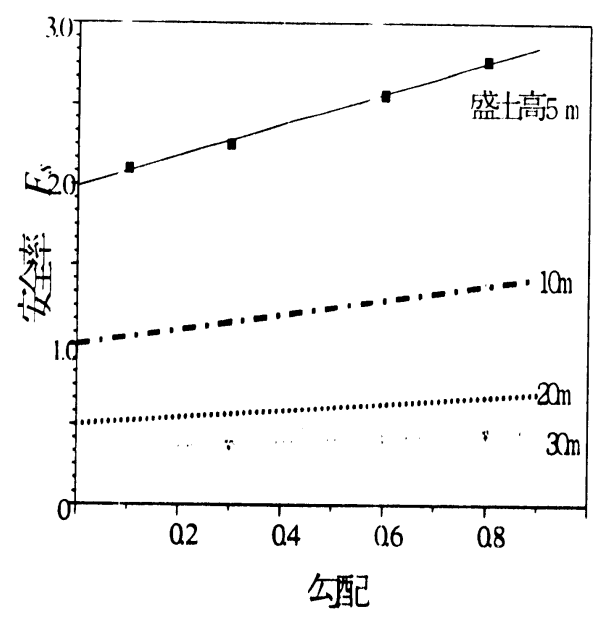

図-5 勾眍の影需

基礎地盤はすべり面が内部を通らない砂磁層とする。

(2)無補強盛土

全く補強されない盛土（締め固めは可能）を想定 し、勾配 1:0.1, 0.3,0.6,0.8 盛土高 5, 10,20,30m の組 合せについて計算を行った。その結果、安全率は図-5 に示すように盛土高ごとに勾配の影響が異なり、それ ぞれ直線的な変化をする。また、限界盛土高 $H_{c}\left(F_{s}=1.0\right.$ の盛土高)は約 $10 \mathrm{~m}$ である。さらに、図-6に示すよう に、図-5の各々の垂直勾配安全率 (切片), 安全率改 善率（傾き）は盛土高に対して反比例で良い相関を示 した。安全率改善率は勾配に対する影響を示すことか ら、盛土高が高くなるにつれ勾配の影響は小さくなる。 (3)排水効果のみを考慮した場合

勾配 1:0.1で排水効果が十分に発揮された状態（無限時間放置した状態）での、盛土高に対する安 全率の変化について計算を行った。その結果、図-7に示すように安全率は盛土高に対して反比例で 良い相関を示した。また、限界盛土高 $H_{\mathrm{c}}$ は $11.8 \mathrm{~m}$ となった。無補強時に比べ安全率で $18 \%$ 程度の有 為な差があり、確実に補強されているものと判断できる。

(4)引張補強効果のみを考慮した場合

勾配 1:0.1 で表-2の敷設方法で、引張補強効果のみを 期待した場合の計算を行った。その結果、図-8に示す ように、どの敷設方法に打いても盛土高 $20 \mathrm{~m}$ は施工不 可能となった。敷設方法(1)〜 (4)の順で常に総定着長が長 いため、同順で安全率が高い結果となった。しかし、盛 土高が高くなるにつれ敷設方法間の差は小さくなる。敷 設方法(1)（4)の順に限界盛土高 $H_{c}$ は 19.1, 18.6, 17.0,

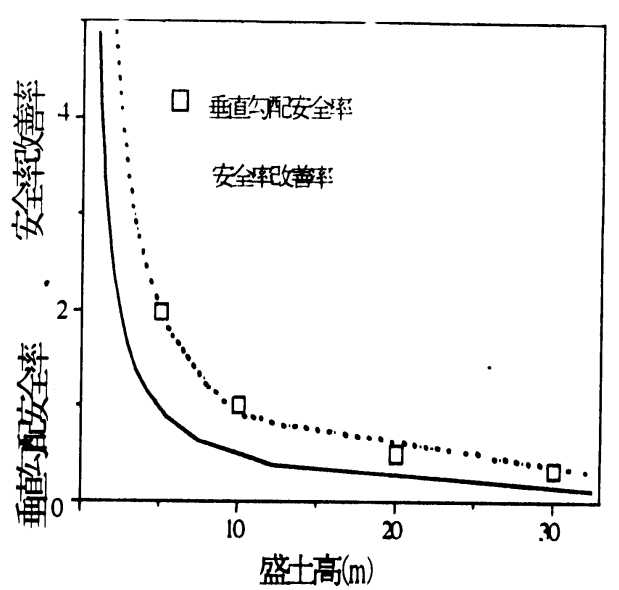

\section{図-6 垂直勾眍安全率, 安全率改書率}

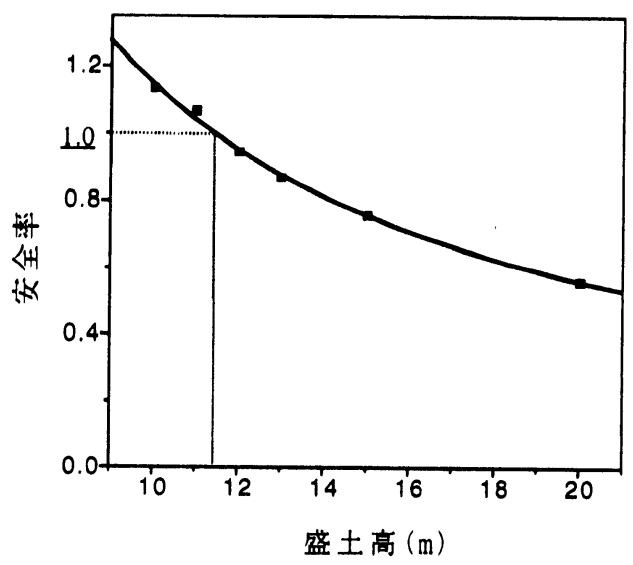

図-7 盛土高-安全率时保

(排水効果のみ)

\section{表-2 数設方法}

\begin{tabular}{|c|c|c|c|c|c|}
\hline \multicolumn{2}{|c|}{ 敷設方法 } & (1) & (2) & (3) & (4) \\
\hline 層 No. & 層圧 & $N_{f}, l e$ & $N_{f}, l e$ & $N_{f}, l e$ & $N_{f}, l e$ \\
\hline 1 & $5 \mathrm{~m}$ & 10,3 & 5,3 & 10,1 & 3,1 \\
\hline 2 & 5 & 3,2 & 9,2 & 10,1 & 3,1 \\
\hline 3 & 4 & 2,1 & 2,1 & 5,1 & 9,1 \\
\hline 4 & 3 & 1,1 & 1,1 & 1,1 & 1,1 \\
\hline 5 & 3 & 1,1 & 1,1 & 1,1 & 1,1 \\
\hline \multicolumn{5}{|c|}{$N_{f}:$ 複合不織布枚数, le : 定着長 $(\mathrm{m})$} \\
\hline
\end{tabular}


15.3mとなった。

(5)両効果を考尛した場合

（）敷設方法の景響

盛土高 $20 \mathrm{~m}$, 夘配 1:0.1の盛土を想定し、泰-2に示す 4 バターンの敷設うj法で計算を行った(図-9参照)。なお、圧 密時間は必要最低圧密時間 $t_{c d}$ に従うとする。その結果、 複合不織布総延拄は敷設方法(4)(273m), (1)(289m), (2) (373m)，(3)(425m)の順で短く、総圧密時間は敷設方法(2)(591 分), (3)(905 分),(1 (8758 分), (4)(16885 分)の順で短い結果を 得た。敷設方法(2)，(3)の比較では、敷設方法2)の方が有効 な敷設法である。排水距離と各盛土段階における総定着長 を比較すると、排水距離は敷設方法(3)の方が短く、総定着

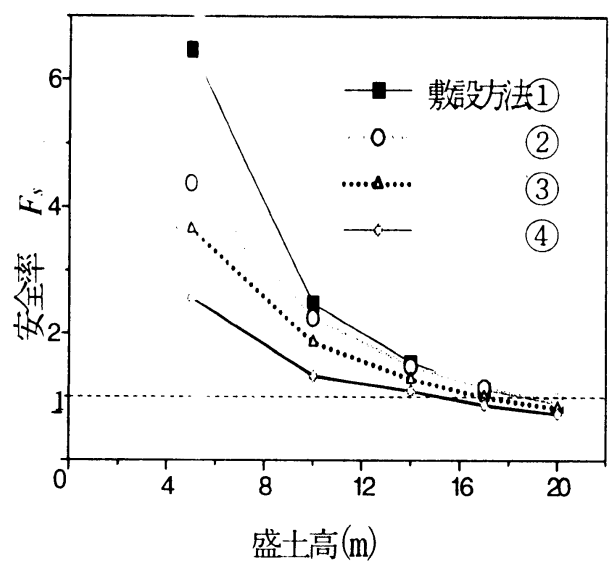

図-8 盛土高-安全率関係

(引張補强効果のみ)

長は(2)の方が常に長い。このことは、複合不織布の引抜き抵抗力が安全率に大きく寄与していること を示す。特に下層の排水距離を短くし、下層の㥹定着長を長くした方が効果的であることが判明した。

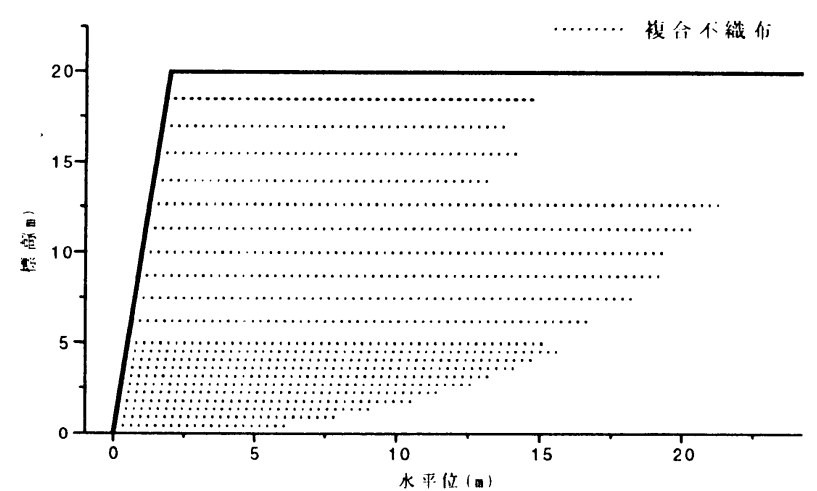

（a）敷設方法(1)

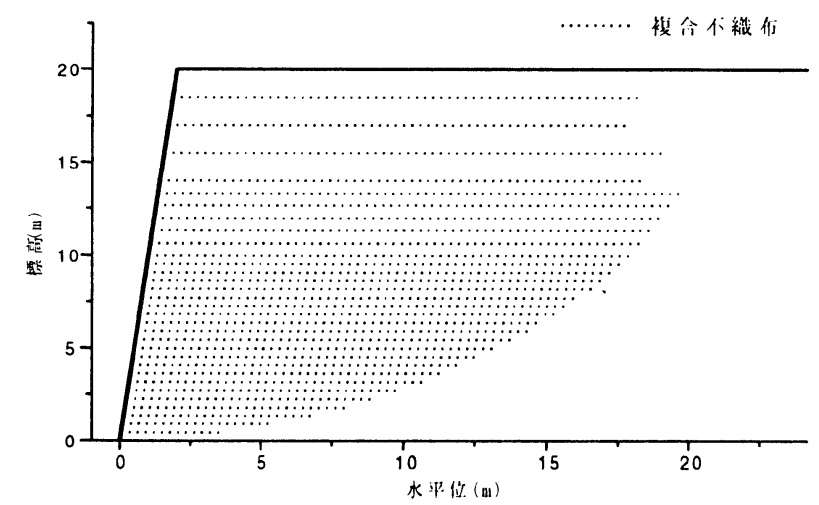

（c）敷設方法(3)

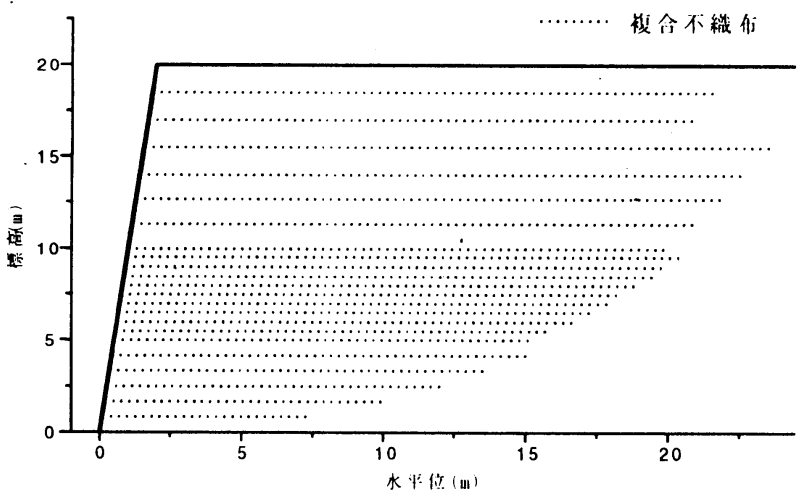

(b) 敷設方法(2)

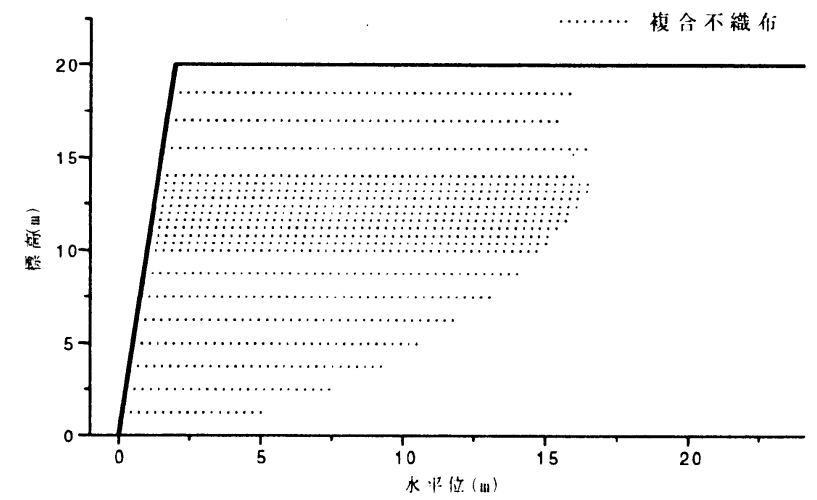

(d) 敷設方法(4)

因-9 䋯設図 


\section{(ii) 施 I: 保の影響}

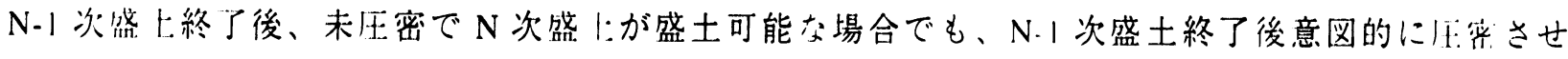

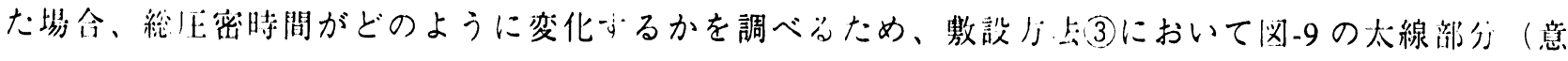
図的に店密させる部分を表す）のパター・ンで計算を行なった。その站果、複合不織布総延長は施 L.1: 程(3) c (378m), a (379m), b (379m), d (425m)の順で短く、総压密時間は施 L工程(3)c(495 分), b(510 分), a(905 分), $\mathrm{d}(955$ 分)の順で短い結果を得た。施工工程(3) $\mathrm{d}$ が意図的な庄密点施さないパターンであり、最も 効率の琹い結果であることから、未圧密で盛土可能な場合でも意図的に圧密させた方が、総圧密時間 を短縮でき、特に盛土初期段階に圧密させた方がより短縮できるこ上が判明した。

(6) 限界盛土高 $H_{c}$ による比較

無補強, 引張効果のみ, 排水効果のみのいずれの場合も限界盛七高 $H_{c}$ より、盛土高 $20 \mathrm{~m}$ は施〔不 可能である結果となった。しかし、引張効果・排水効果の両効果を考慮した場合、敷設方法(1) 4)の どの場合でも盛土高 $20 \mathrm{~m}$ は施工可能の結果を得た。よって、両効果を考慮することで、より経济的 な設計が可能になったと言える。

\section{6. まとめ}

実験に用いた複合不織布は、関東ロームに対して引張補強材として十分な摩擦特性を示した。複 合不織布の排水効果扰よび引張補強効果を同時に考慮した設計法を提示した。どちらか一方の効果を 考慮した場合に盛土施工不可と判断される場合でも、両効果を考慮した提案設計法では盛土施工可と 判断されることから、複合不織布の特性を十分に考慮できる設計法であると考える。また、施工過程 をイメージしながら安定性の判断を行うことができるため、工程管理を考慮に入れた設計法が容易に できる特徵も有している。

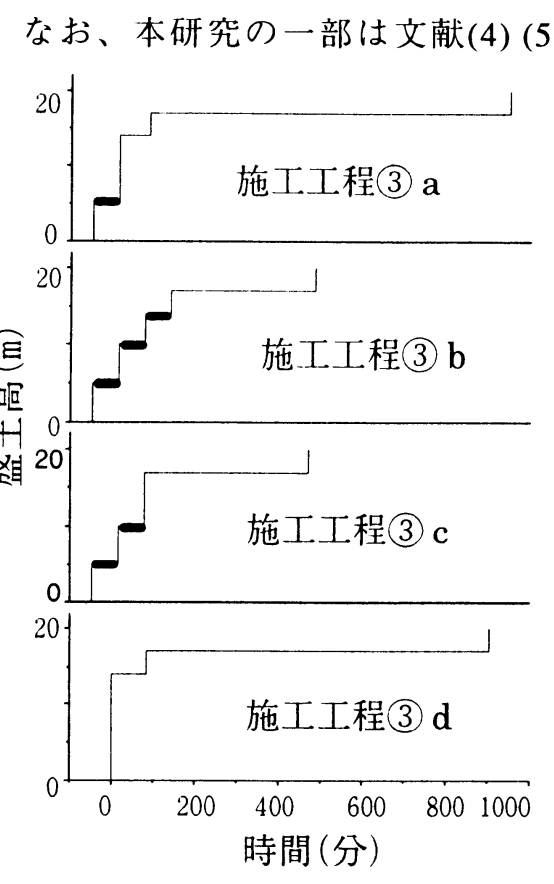

図-10 盛土施工工程（計算桔果）
参考文献

1)ジオテキスタイル補強盛土工法普及委員会, ジオテキスタイ ルを用いた設計・施エマニュアル,pp. 51-83,1996

2)山口伯樹, 土質力学 (全改訂), pp. 121-122, 技報堂, 1984

3)陶山・棚橋·和久田·安原・西村, 高含水比火山兏粘性土と複合 ファブリックの一面せん断試験による摩擦特性の把握, 平成 8 年度土木学会西部支部研究発表会講演概要集, III -57, pp. 480481,1997

4)和久田・棚橋・陶山・安原・西村, 圧密による強度増を考慮した 急勾配補強盛土の設計法試案, 平成 8 年度土木学会西部支部研 究発表会講演概要集, 血-126,pp.614-615, 1997

5)棚橋・和久田・陶山・安原・西村, 圧密による強度増と複合不織 布の補強効果を考慮した急勾配補強盛土の設計法の試案, 第 32 回地盤工学研究発表会, pp. 2557-2558, 1997 